\title{
Critical phosphorus levels and availability for castor oil plant grown in different soil classes of Brazil
}

\section{José Félix de Brito Neto ${ }^{1}$, Leonardo Theodoro Büll ${ }^{2}$, André Luiz Pereira da Silva ${ }^{3 *}$, Leandro Silva do Vale $^{4}$, João Paulo Gonsiorkiewicz Rigon ${ }^{5}$}

\author{
${ }^{1}$ Department of Soil Fertility, Universidade Estadual da Paraíba - UEPB, Lagoa Seca, Paraíba, Brazil \\ ${ }^{2}$ Department of Soil, Universidade Estadual Paulista - UNESP, Botucatu, São Paulo, Brazil \\ ${ }^{3}$ Department of Exact Sciences, Universidade Estadual Paulista - UNESP, Jaboticabal, São Paulo, Brazil \\ ${ }^{4}$ Department of Production Plant, Universidade Estadual do Maranhão - UEMA, Balsas, Maranhão, Brazil \\ ${ }^{5}$ Department of Agriculture, Universidade Estadual Paulista - UNESP, Botucatu, São Paulo, Brazil
}

\section{*Corresponding author: andreengagronomo@gmail.com}

\begin{abstract}
The current study aims to determine critical P levels in different soil classes and their availability for castor bean initial growth. Extraction was done using Mehlich-1 and ion-exchange resin. The experiment was conducted in a greenhouse, in a randomized blocks design with the application of five P doses, which were previously set for each of the four experimental soils (TCo: Chromic Orthic Luvisol; CXbe: Eutrophic Haplic Cambisol; CXve: Typical Eutrophic Cambisol; RY: Fluvic), with four repetitions for 40 days. In the end of the experiment, plants were harvested and shoot dry mass was weighted. At the time plants were collected, samples were gathered to determine soil $\mathrm{P}$ availability through Mehlich-1 and ion-exchange resin. Mehlich-1 was more efficient in phosphorus recovery in the following soils: TCo, CXbe and CXve, regardless of applied dose. Critical P levels ranged from 21.33 to $416.64 \mathrm{mg} \mathrm{dm}^{-3}$ due to the clay content in Mehlich-1, and from 30.70 to $177.55 \mathrm{mg} \mathrm{dm}^{-3}$ in resin. MPAC presented positive coefficients regarding soil clay content. The highest castor bean shoot dry mass production was found in CXve and TCo soils. It

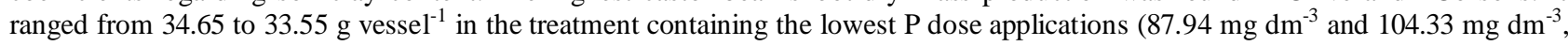
respectively).
\end{abstract}

Received 16 March 2016; Revised 13 Jan 2017; Accepted 7 March 2017.

Keywords: Extractors; adsorption; nutrition, precipitates; aluminum.

Abbreviations: TCo_Chromic Orthic Luvisol; CXbe_Eutrophic Haplic Cambisol; RY_Fluvic; CXve_Typical Eutrophic Cambisol; Rem-P_remaining phosphorus; MPAC_maximum phosphorus adsorption capacity.

\section{Introduction}

$\mathrm{P}$ is a macronutrient required by plants in lower amounts, despite its importance to plants' growth and development. It is one of the factors that limit yield in most crops (Xie et al., 2014). Suboptimal $P$ fertilizer input may lead to poor growth and malfunctioning in plants, whereas over optimal $\mathrm{P}$ input may lead to low P efficiency (Ma et al., 2012). Most Brazilian soils have high weathering degree, large iron and aluminum oxide amounts and clay belonging to the kaolinite minerals group, which is characterized by surface charges presence, varying according to the soil solution reaction (Torres et al., 2016). Thus, soil can work as P source, showing good $\mathrm{P}$ input capacity to plants, or as drainer, since it strongly competes for $\mathrm{P}$ in the plant and leaves. However, most of the added phosphorus is fixed to soil colloids and unavailable to plants (Pavinatto et al., 2009).

As weathering increases, the soil becomes more electropositive and adsorbs more anions, such as phosphates (Novais and Smyth, 1999). Many of these highly weathered and even less weathered soils, besides having lower total P content, appear to lack P availability. Low solubility, found in most $\mathrm{P}$ forms, and/or the strong interaction between phosphate and the soil, in order to form low solubility compounds in different soils, is associated with different combinations of iron, aluminum, calcium, organic matter and other elements (Rolim Neto et al., 2004). To know the P level available in the soil is very important to carry out phosphorus fertilization properly, in order to increase castor oil plant yield, mainly in Brazil's Northeastern region, which is responsible for its largest crops.

Therefore, the current study aims to determine critical $\mathrm{P}$ levels in four soil classes and their availability to castor bean plants, through Mehlich-1 and ion-exchange Resin.

\section{Results and Discussion}

$\mathrm{P}$ concentrations in the soils originally checked (Table 1) are classified depending on their distance from the ground and on high RY in TCo, CXbe and CXve soils. Extraction-recovered $\mathrm{P}$ amount was different depending on soil type and extractor used (Table 2). Resins should theoretically work similarly with roots because they adsorb $\mathrm{P}$ from the solution and gradually consume the soil labile $\mathrm{P}$, which has different chemical, physical and mineralogical properties (Gatibonni et al., 2005). 


\section{Settings}

A more linear determination coefficient set the ion-exchange resin by regression equations between the applied $\mathrm{P}$ doses and the recovered $\mathrm{P}$ amounts by the extractors used. $\mathrm{P}$ concentrations used were recovered by extracting the high variability of treatments that were not supplied with $\mathrm{P}$ (Table 2), demonstrating the difference among soils and available $P$ reserves. Extractors were somehow influenced by the buffering capacity, which predicts soil nutrient resistance during desorption (Novais and Smyth, 1999).

\section{Extractors used}

Among extractors used, Mehlich-1 was the one that have recovered more $\mathrm{P}$, regardless of the dose applied to TCo, CXbe and CXve soils (Table 2). Such behavior can be explained by the fact that these soils presented low acidity, favoring the formation of compounds such as poorly soluble calcium phosphate (P-Ca), which probably occurred in these soils due to its high $\mathrm{Ca}$ level and $\mathrm{pH}$ value close to neutrality. Thus, Mehlich-1-recovered $\mathrm{P}$ levels may have been overestimated because the extractor can displace $\mathrm{P}$ bound to $\mathrm{Ca}, \mathrm{Fe}$ and $\mathrm{Al}$ oxides, which are unavailable forms to plants. According to Torres et al., (2016), acid extractors predominantly dissolve $\mathrm{P}$ when it is attached to Ca. Small $\mathrm{P}$ amounts bound to $\mathrm{Fe}$ and $\mathrm{Al}$, depending on phosphates solubility features, allowing for inferring whether extractors are less suitable acids for humid tropical region soils, which have kaolinite, iron and aluminum oxides prevalence in the soil clay fraction. However, the anion exchange resin Q in RY extracted more Mehlich-1 (Table 2). It is likely that this behavior is related to high $\mathrm{pH}$ and high clay content, which probably caused Mehlich-1 wear. It did not occur with the Resin due to the soil Resin solution stirring period (Alcântara et al., 2008).

According to Novais and Smyth (1999), soils with higher clay content and high acidity buffering capacity rapidly increased the initial Mehlich-1 $\mathrm{pH}$ to values close to those of the soil. As the $\mathrm{SO}_{4}{ }^{2-}$ found in the extractor worked in exchange with the adsorbed $\mathrm{P}$, it was quickly adsorbed by the adsorption sites, which were not occupied by P. Thus, the combined action performed by these phenomena was responsible for Mehlich-1 decreased P extraction power. The $\mathrm{P}$ possibly added to the soils was preferentially adsorbed by soil colloids, in order to form $\mathrm{P}-\mathrm{Al}$ and $\mathrm{P}-\mathrm{Fe}$ and precipitate with calcium found in the soil, which formed P-Ca

Mehlich-1 extracted larger P amounts than those of Resin, and the extraction was inversely proportional to the clay content. Torres et al., (2016) found higher Mehlich-1 efficiency in comparison to that of the Resin when they evaluated Hapludox with $800 \mathrm{~g} \mathrm{~kg}^{-1}$ clay. The ion-exchange Resin was poorly influenced by the soil buffering capacity and showed no extractor wear. Stress got worse as clay content increased (especially kaolinite and $\mathrm{Fe}$ and $\mathrm{Al}$ oxides); it multiplied the specific surface potentially attacked by the chemical agents used in the extractors.

\section{Soil P Availability}

Table 2 presents $\mathrm{P}$ recovered levels regression equations associated with the amount applied for each extractor. The obtained correlation coefficients were above $82 \%$, indicating that both extractors were efficient in predicting soil $\mathrm{P}$ availability. $\mathrm{P}$ extracted by Mehlich-1 from CXbe, RY and CXve soils provided adjusted equations that were able to explain more than $85 \%$ variation in $\mathrm{P}$ extracted levels. More than $95 \%$ variation in ion-exchange Resin P concentrations were explained by the adjusted equations for CXve and CXbe soils, but not for RY. According to Silva and Raij (1999), in theory, the ion-exchange Resin extracted soil phosphorus similarly to plant absorption, and it explains the best result found with this extractor. Büll et al. (1998) demonstrated this method's good ability of predicting $\mathrm{P}$ availability in soils from different cultures.

Overall, critical P levels varied due to clay content, which ranged from 21.33 to $416.64 \mathrm{mg} \mathrm{dm}^{-3}$ in the Mehlich-1 experiment, and from 30.70 to $177.55 \mathrm{mg} \mathrm{dm}^{-3}$ in the ionexchange Resin experiment (Table 3). Such variation is probably related to chemical, physical and mineralogical soil variability in each study. According to Alvarez et al. (1990), the critical level corresponds to the element content in the plant or in the soil. Growth or production rate significantly decreased below such level, indicating the need for supplementary fertilization. The critical level of an element is related to the element concentration in the soil, being responsible for $90 \%$ or $100 \%$ of its production. Thus, higher critical level is expected in soils with low maximum $\mathrm{P}$ adsorption capacity (MPAC). Therefore, the lesser $\mathrm{P}$ is absorbed by the soil, the more it is available to plants. The results of the current study show that the critical $\mathrm{P}$ level in the soil was lower in clayey soils, as it was observed in RY, which has $330 \mathrm{~g} \mathrm{~kg}^{-1}$ clay and consequently higher FCP (Table 3), a fact that corroborates with the results found in the literature.

\section{Critical phosphorus levels in soils}

CXve and TCo soils were less clayey (125.4 g $1 \mathrm{~kg}$ and 135.6 $\mathrm{g} \mathrm{kg}^{-1}$, respectively), and critical levels increase appeared to be highly critical; CXbe had $254.9 \mathrm{~g} \mathrm{~kg}^{-1}$ clay and consequently the highest $\mathrm{P}$ adsorption capacity (Table 3 ). In addition, the natural clay content interfered in soil critical $\mathrm{P}$ levels, as it was reported by Boem et al. (2011). Overall, such results demonstrate that soil critical $\mathrm{P}$ levels are higher in less clayey soils. Knowledge on critical nutrition levels in the soil and plant tissues enables a more precise recommendation on the fertilizer amount to be applied. According to Novais and Smyth (1999), competition between the plant and P-treated soil makes the plant adjust and use the available $\mathrm{P}$ more efficiently. Thus, when $\mathrm{P}$ is the only limiting factor to production, besides variations resulting from species or cultivars and plant tissues age, nutrient interaction among nutrients, environmental conditions and soil properties reflect $\mathrm{P}$ capacity. Therefore, they should also be taken under consideration in the interpretation of critical $\mathrm{P}$ levels in plants (Simões Neto et al., 2011).

\section{Correlation coefficients}

Linear correlation analysis was performed to verify the relationship between the critical $\mathrm{P}$ level in the soil by Mehlich-1 anion exchange Resin extractors and soil attributes (Table 4). There was significant and positive correlation between MPAC and clay content, and high correlation coefficient. The clay fraction (iron and aluminum oxides and kaolinite) is responsible for the specific $\mathrm{P}$ adsorption phenomenon, establishing a direct relationship with MPAC. There was significant and negative coefficient for the most critical P level in the soil by Mehlich-1 extraction with MPAC, despite the low correlation coefficient between soil critical $\mathrm{P}$ levels by the extractors studied. Therefore, the 
Table 1. Soil Physicochemical features.

\begin{tabular}{|c|c|c|c|c|}
\hline \multirow[b]{2}{*}{ Features } & \multicolumn{4}{|c|}{ Soils } \\
\hline & TCo & CXbe & RY & CXve \\
\hline $\mathrm{pH} \mathrm{H}_{2} \mathrm{O}(1: 2,5)$ & 6.8 & 6.6 & 6.8 & 6.5 \\
\hline $\mathrm{Ca}^{+2}\left(\mathrm{mmol}_{\mathrm{c}} \mathrm{dm}^{-3}\right)$ & 76.9 & 182.1 & 145.3 & 31.0 \\
\hline $\mathrm{Mg}^{+2}\left(\mathrm{mmol}_{\mathrm{c}} \mathrm{dm}^{-3}\right)$ & 29.5 & 39.3 & 63.5 & 20.5 \\
\hline $\mathrm{Na}^{+}\left(\mathrm{mmol}_{\mathrm{c}} \mathrm{dm}^{-3}\right)$ & 1.1 & 0.7 & 1.1 & 0.5 \\
\hline $\mathrm{K}^{+}\left(\mathrm{mmol}_{\mathrm{c}} \mathrm{dm}^{-3}\right)$ & 5.1 & 13.5 & 4.8 & 6.2 \\
\hline $\mathrm{SB}\left(\mathrm{mmol}_{\mathrm{c}} \mathrm{dm}^{-3}\right)$ & 112.6 & 235.6 & 214.7 & 58.2 \\
\hline $\mathrm{H}+\mathrm{Al}\left(\mathrm{mmol}_{\mathrm{c}} \mathrm{dm}^{-3}\right)$ & 12.4 & 38.0 & 28.1 & 12.4 \\
\hline $\mathrm{T}\left(\mathrm{mmol}_{\mathrm{c}} \mathrm{dm}^{-3}\right)$ & 125.0 & 273.6 & 242.8 & 70.6 \\
\hline $\mathrm{V}(\%)$ & 90 & 86 & 88 & 82 \\
\hline $\left.\mathrm{Al}^{+3} \mathrm{mmol}_{\mathrm{c}} \mathrm{dm}^{-3}\right)$ & 0.5 & 0.5 & 0.5 & 0.5 \\
\hline P mg dm ${ }^{-3}$ (Mehlich 1) & 296.2 & 286.8 & 8.90 & 22.5 \\
\hline P mg dm ${ }^{-3}($ Resin $)$ & 75.0 & 130.5 & 10.5 & 18.0 \\
\hline M.O $\left(\mathrm{g} \mathrm{kg}^{-1}\right)$ & 11.2 & 28.8 & 20.9 & 10.2 \\
\hline Rem-P $\left(\mathrm{mg} \mathrm{L}^{-1}\right)$ & 43.73 & 16.28 & 27.34 & 41.34 \\
\hline $\operatorname{MPAC}\left(\mathrm{mg} \mathrm{g}^{-1}\right)$ & 0.279 & 0.297 & 0.395 & 0.293 \\
\hline Sand $\left(\mathrm{g} \mathrm{kg}^{-1}\right)$ & 726.4 & 716.8 & 450.1 & 726.6 \\
\hline Silt $\left(\mathrm{g} \mathrm{kg}^{-1}\right)$ & 138.0 & 28.3 & 234.8 & 148.0 \\
\hline Clay $\left(\mathrm{g} \mathrm{kg}^{-1}\right)$ & 135.6 & 254.9 & 330.0 & 125.4 \\
\hline
\end{tabular}

TCo: Chromic Orthic Luvisol; CXbe: Eutrophic Haplic Cambisol; RY: Fluvic; CXve: Typical Eutrophic Cambisol. SB: sum of bases; T: cation exchange capacity; V (\%) base saturation; Rem-P: remaining phosphorus; MPAC: maximum phosphorus adsorption capacity.
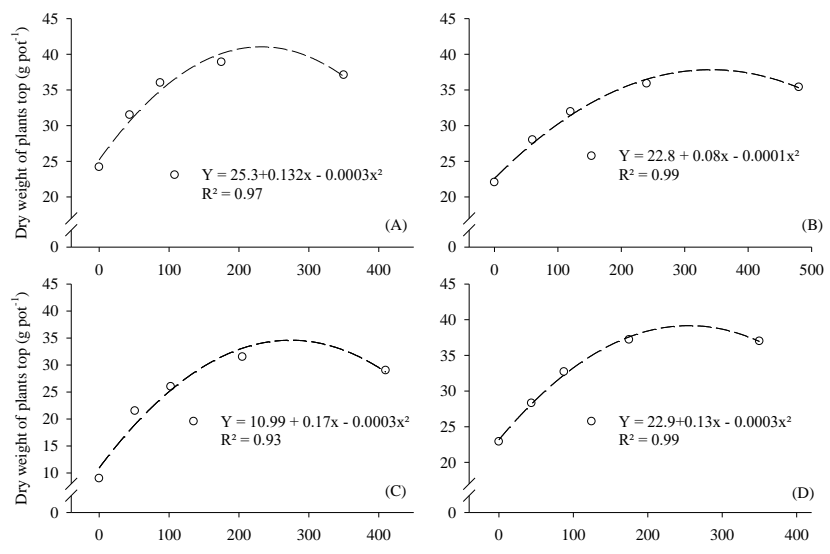

Fig 1. P rates estimated for $90 \%$ of maximum shoot dry mass for TCo (A), CXbe (B), RY (C) and CXve (D) soils.

Table 2. Regression equation estimators for $\mathrm{P}$ recovered by Mehlich-1 and Resin, depending on the $\mathrm{P}$ doses applied to the four soil classes.

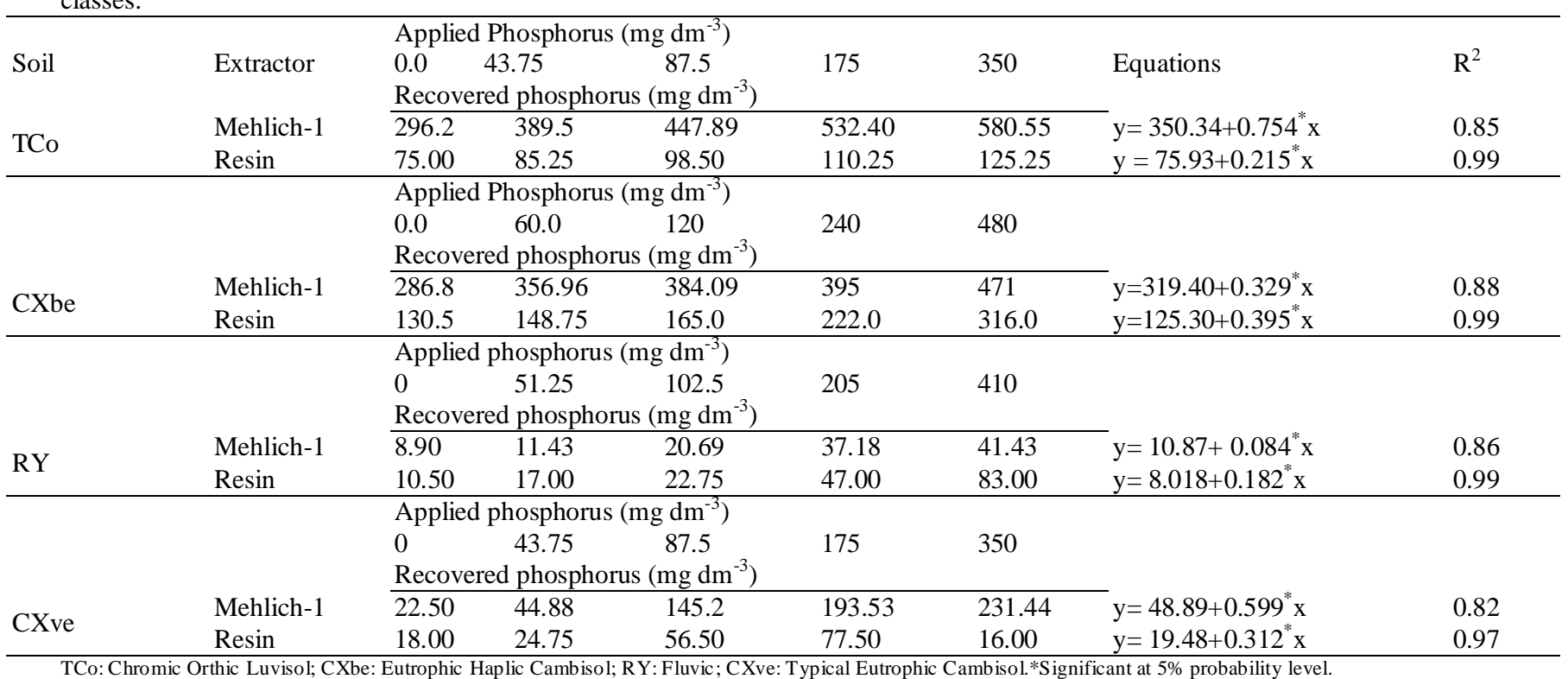


Table 3. Soil critical P levels by Mehlich-1 and ion-exchange Resin in order to obtain $90 \%$ of maximum production.

\begin{tabular}{|c|c|c|c|c|}
\hline \multirow{3}{*}{ Soil } & \multirow{3}{*}{$\begin{array}{c}\text { Clay } \\
---\mathrm{g} \mathrm{kg}^{-1}----\end{array}$} & \multirow{3}{*}{$\begin{array}{c}\text { Prem } \\
\mathrm{mg} \mathrm{L}^{-1}-{ }_{-}\end{array}$} & \multicolumn{2}{|c|}{ Soil critical P level } \\
\hline & & & Mehlich-1 & Resin \\
\hline & & & \multicolumn{2}{|c|}{----------mg dm ${ }^{-3}$} \\
\hline TCo & 135.6 & 43.73 & 416.64 & 94.83 \\
\hline CXbe & 254.9 & 16.28 & 362.28 & 177.51 \\
\hline RY & 330.0 & 27.34 & 21.33 & 30.70 \\
\hline CXve & 125.4 & 41.34 & 111.33 & 52.03 \\
\hline
\end{tabular}

Table 4. Simple linear correlation coefficients between soil critical P levels by Mehlich-1 and anion exchange Resin, showing soil chemical properties.

\begin{tabular}{|c|c|c|c|c|c|c|c|}
\hline Variables & $\operatorname{MPAC}^{(1)}$ & $\mathrm{EL}^{(2)}$ & $\mathrm{FCPm}^{(3)}$ & Prem $^{(4)}$ & Clay $^{(5)}$ & $\mathrm{NCM}^{(6)}$ & $\mathrm{NCR}^{(7)}$ \\
\hline MPAC & & $-0.77 * *$ & $-0.08 n s$ & $-0.33 n s$ & $0.83 * *$ & $-0.71 * *$ & $-0.49 *$ \\
\hline EL & & & $0.62 * *$ & $0.30 \mathrm{~ns}$ & $-0.91 * *$ & $0.17 \mathrm{~ns}$ & $-0.05 n s$ \\
\hline FCPm & & & & $0.05 \mathrm{~ns}$ & $-0.33 n s$ & $-0.58 *$ & $-0.56 n s$ \\
\hline Rem-P & & & & & $0.36 \mathrm{~ns}$ & $0.14 \mathrm{~ns}$ & $-0.02 \mathrm{~ns}$ \\
\hline Clay & & & & & & $-0.38 n s$ & $0.03 \mathrm{~ns}$ \\
\hline
\end{tabular}

(1) Soil critical P level by resin extraction, (2) Soil critical P level in the soil by Mehlich-1 extraction, (3) Soil clay content ( $\left.\mathrm{g} \mathrm{kg}^{-1}\right)$, (4) Remaining phosphorus (Alvarez V. et al., 2000), (5) P capacity factor, (6) Binding energy, (7) P maximum adsorption capacity.

higher the clay content, the lower the critical level. It is common to find significant and positive correlations between soil clay content and MPAC in the literature (Valladares et al., 2003; Falcão and Silva, 2004).

Although adsorption energy is not correlated to critical $\mathrm{P}$ levels by the studied extractors, there was significant negative correlation between FCPm and the critical P level by Mehlich-1extraction; however, there was no correlation between Prem, clay content and critical P level in the two extractors tested (Table 4).

\section{Shoot maximum dry matter yield}

Response curves used to explain castor bean shoot dry mass production resulting from $\mathrm{P}$ rates applied to TCo, CXbe, RY and CXve are presented in Figure 1. P rate applications led to shoot dry mass production increase, which was adjusted to high determination coefficient quadratic models. There was shoot dry mass production variation from 34.65 to $33.55 \mathrm{~g}$ vessel $^{-1}$, respectively, (Figure 1A and 1D) in TCo and CXve soils. $\mathrm{P}$ input increased plant height, stem diameter and leaf area in castor oil plants (Brito Neto et al., 2014). These soils were responsible for higher shoot dry mass production due to the application of lower P doses $\left(87.94 \mathrm{mg} \mathrm{dm}^{-3}\right.$ and 104.33 $\mathrm{mg} \mathrm{dm}{ }^{-3}$, respectively). Such production was directly related to the low clay content of these soils and, consequently, to their lower phosphate adsorption capacity and greater $\mathrm{P}$ availability to plants.

Soils with high clay content (CXve and RY) showed shoot dry mass production variations from 31.86 to $27.43 \mathrm{~g} \mathrm{vessel}^{-}$ 1 , respectively, and such production was related to higher $\mathrm{P}$ doses $\left(132.18 \mathrm{mg} \mathrm{dm}^{-3}\right.$ and $\left.124.63 \mathrm{mg} \mathrm{dm}^{-3}\right)$. It demonstrates $\mathrm{P}$ drain character and the lack of $\mathrm{P}$ availability to plants (Figure 1B and 1C, respectively), with higher adsorption. These results demonstrate that it took a higher $\mathrm{P}$ dose with higher FCP (CXbe and RY) values for shoot dry mass production, showing the character of these soils.

According to Novais and Smith (1999), data available in the literature show that plants adjust to $\mathrm{P}$ increased use in soils with high MPAC and FCP values. Based on the results of this study, the importance of clay to adsorption and of $\mathrm{P}$ availability to the plants is evident. Novais and Smyth (1999) reported that, in soils with high FCP values, as is the case of RY and CXbe (Figure 1B and 1C), plants optimize the lowest $\mathrm{P}$ concentration in the available solution (intensity factor), producing more biomass per absorbed $\mathrm{P}$ unit than soils with lower FCP values.

\section{Materials and Methods}

\section{Experimental site}

The experiment was conducted in greenhouse at the National Center for Cotton Research. Climate was tropical wet, according to Köppen classification. Mean annual temperature is $28.6^{\circ} \mathrm{C}$

Samples of four soils with different chemical, physical and mineralogical attributes were collected at $0-30 \mathrm{~cm}$ below the soil surface, corresponding to the plow layer. Subsequently, they were taken to the experiment site. Soil samples were grounded, air-dried and sieved through a $2-\mathrm{mm}$ mesh, in order to be physically and chemically characterized (Table 1), according to Embrapa (1997). The experimental design consisted of a completely randomized design comprising 20 treatments (4 soils $\mathrm{x} 5$ phosphorus levels) and four repetitions, totaling 80 experimental units. Each experimental unit consisted of a plastic vessel containing $20 \mathrm{dm}^{-3}$ of soil and BRS Energia castor plant.

\section{Treatments and experimental design}

The soil was sieved through a 4-mm mesh after being grounded and air-dried. Subsequently, vessels were packed with $23 \mathrm{~kg}$ of soil. Each soil type received five P doses (0.0, $43.75,87.5,175$, and $350 \mathrm{mg} \mathrm{dm}^{-3}$ for TCo and CXve), (0.0, $60,120,240$ and $480 \mathrm{mg} \mathrm{dm}^{-3}$ for CXbe) and (0.0, 51.25, 102.5, 205 and $410 \mathrm{mg} \mathrm{dm}^{-3}$ for RY). Triple superphosphate was used as P source, according to the remaining P (Prem), and followed the methodology by Alvarez et al. (2000). Triple superphosphate was applied and homogenized in $100 \%$ of the soil volume in each vessel. A nutrient solution was applied (Hoagland and Arnon, 1950); the solution contained all the essential nutrients except for $\mathrm{P}$, which was used as treatment.

\section{Characteristics evaluated}

After the soil P levels of each vessel were assessed, samples were incubated for 15 days. Afterwards, distilled water was added to them ( $70 \%$ of field capacity of each soil type). After the incubation period, $0.2 \mathrm{dm}^{-3}$ of soil subsamples were 
removed from each vessel to determine $\mathrm{P}$ availability by Mehlich-1 (Embrapa, 1997) and anion exchange resin. The vessels were regularly watered with distilled water (the remaining $70 \%$ of its field capacity); the water requirement was set by weighing the vessel by weight per block of four vessels.

Three BRS Energia castor seeds were sowed in each vessel; thinning was performed ten days after emergence, making the plants more vigorous. Forty days after germination, plant shoots from each vessel were cut $1 \mathrm{~cm}$ from the ground, separating the plant shoot (stem and leaf) from the root. The plant material was washed in running water and then in distilled water. Subsequently, the material was oven-dried under forced air circulation at $65^{\circ} \mathrm{C}$ until constant weight was obtained. The material was then weighed on an analytical scale, in order to get shoot dry mass.

\section{Data analysis}

Regression equations were adjusted to relate shoot dry mass and $\mathrm{P}$ dose variation, applied to $\mathrm{P}$ contents recovered by Mehlich-1 and ion-exchange Resin. The dose was set on $90 \%$ of the maximum value due to the importance of working with maximum economic efficiency doses. This value was replaced in the regression equations by the extractionrecovered $\mathrm{P}$, using the added $\mathrm{P}$ amount as a function of the critical P level in the soil. Data were subjected to analysis of variance and polynomial regression, in order to match dependent variables and treatments.

\section{Conclusion}

Soil critical P level, determined for $90 \%$ of maximum castor bean dry mass production, was $21.33 \mathrm{mg} \mathrm{dm}^{-3}$ for RY; as for TCo, application of $87.94 \mathrm{mg} \mathrm{dm}^{-3} \mathrm{P}$ led to the greatest castor bean shoot dry mass production increase (34.65 $\left.\mathrm{g} \mathrm{vessel}^{-1}\right)$.

\section{References}

Alcântara FA, Furtini Neto AE, Curi N, Resende AV (2008) Extraction methods for phosphorus and their relationship with soils phosphorus-buffer capacity estimated by the remaining-phosphorus methodology-a pot study with maize. Commun Soil Sci Plan. 39:603-615.

Alvarez VH, Fonseca DM (1990) Determinação de doses de fósforo para determinação da capacidade máxima de adsorção de fosfatos e para ensaios em casa de vegetação. Rev Bras Cienc Solo. 14:49- 55.

Alvarez VH, Novais RF, Dias LE, Oliveira JA (2000) Determinação e uso do fósforo remanescente. Boletim Informativo. Sociedade Brasileira de Ciência do Solo, Viçosa, MG. 25:27-32.

Bahia Filho AFC, Braga JM, Resende M, Ribeiro AC (1983) Relação entre adsorção de fósforo e componentes mineralógicos da fração argila de Latossolo do planalto central com diferentes características texturais e mineralógicas. Rev Bras Cienc Solo. 7:221-226.

Bates TE (1971) Factors affecting critical nutrient concentrations in plants and their evaluation: a review. Soil Sci. 112:116-130.

Boem FHG, Rubio G, Barbero D (2011) Soil Phosphorus Extracted by Bray 1 and Mehlich 3 Soil Tests as Affected by the Soil/Solution Ratio in Mollisols. Commun Soil Sci Plan. 42:220-230
Brito Neto JF.de, Büll LT, Beltrão NEDM, Rigon JPG, Sofiatti V (2014) Absorption and critical levels of phosphorus in castor bean shoots grown in different soil classes. Semina. 35:239-250.

Büll LT, Forli F, Tecchio MA, Corrêa JC (1998) Relações entre fósforo extraído por resina e respostas da cultura do alho vernalizado à adubação fosfatada em cinco solos com e sem adubação orgânica. Rev Bras Cienc Solo. 22:459470.

[ Embrapa (1997) Centro Nacional de Pesquisa de Solos. Manual de métodos de analise de solo. 2. ed. rev. atual. Rio de Janeiro, $212 \mathrm{p}$.

Falcão NPS, Silva JRA (2004) Características de adsorção de fósforo em alguns solos da Amazônia Central. Acta Amaz. 34:337-342.

Gatiboni LC, Kaminski J, Santos DR (2005) Modificações nas formas de fósforo do solo apósextrações sucessivas com Mehlich-1, Mehlich-3 e Resina trocadora de ânions. Rev Bras Cienc Solo. 29: 363-371.

Hoagland DR, Arnon DL (1950) The water culture methods for growin plants without soil. Berkeley: Agriculture Experiment Station, $32 \mathrm{p}$.

Ma L, Velthof FH, Wang W, Qin WF, Zhang Z, Liu M (2012) Nitrogen and phosphorus use efficiencies and losses in the food chain in China at regional scales in 1980 and 2005. Sci. Total Environ. 434: 51-61.

Novais RF, Smith TJ (1999) Fósforo em solo e planta em condições tropicais. Viçosa: Universidade Federal de Viçosa. 399p.

Olsen SR, Khasawneh FE (1980) Use and limitations of physical-chemical criteria for assessing the status of phosphorus in soils. In: Khasawneh FE. et al. (Eds.). The role of phosphorus in agriculture. American Society of Agronomy. p. 361-410.

Pavinato PS, Merlin A, Rosolem CA (2009) Phosphorus fractions in Brazilian Cerrado soils as affected by tillage. Soil Till Res. 105:149-155.

Rolim Neto FC, Schaefer CEGR, Costa LM, Corrêa MM, Fernandes Filho o EI, Ibraimo MM( 2004) Adsorção de fósforo, superfície específica e atributos mineralógicos em solos desenvolvidos de rochas vulcânicas do Alto Paranaíba, Minas Gerais Rev Bras Cienc Solo. 28: 953964.

Silva FCda, Raij BV (1999) Disponibilidade de fósforo em solos avaliada por diferentes extratores. Pesq. agropec. bras. 34: 267-288.

Simões Neto DE, Oliveira AC, Rocha AT, Freire FJ, Freire MBGS, Nascimento CWA (2011) Níveis críticos de fósforo em solos cultivados com cana-de-açúcar em Pernambuco. Revista Ceres. 58:802-810.

Torres FE, Teodoro PE, Hernandes, FB, Fernandes, RL, Gomes, AC, Lopes KV (2016) Agronomic performance of castor under different growing conditions. Biosci J. 32: 5560.

Valladares GS, Pereira MG, Anjos LHC (2003) Phosphate sorption in low activity clay soils. Bragantia. 62:111-118.

Xie Y, Niu J. Gan Y, Li A (2014) Optimizing phosphorus fertilization promotes dry matter accumulation and $\mathrm{P}$ remobilization in oilseed flax. Crop Sci. 54:1729-1736. 